\title{
Eosinophils Express Interleukin 5 and Granulocyte Macrophage-Colony- stimulating Factor mRNA at Sites of Allergic Inflammation in Asthmatics
}

\author{
David H. Broide, Mary M. Paine, and Gary S. Firestein \\ Department of Medicine, University of California, San Diego, San Diego, California 92103
}

\begin{abstract}
IL-5 and granulocyte macrophage-colony-stimulating factor (GM-CSF) are important regulators of eosinophil survival, proliferation, and effector function. To determine whether IL-5 and / or GM-CSF are generated by eosinophils at sites of allergic inflammation, we have used in situ hybridization with ${ }^{35} \mathrm{~S}$ labeled RNA probes to study the expression of IL-5 and GMCSF mRNA in bronchoalveolar lavage (BAL) eosinophils derived from asthmatics $(n=5)$ before and after endobronchial allergen challenge. Endobronchial allergen challenge induced a significant airway eosinophilia (pre-allergen challenge $0.6 \pm 0.5 \%$ eosinophilia vs post-allergen challenge $48.2 \pm 25.6 \%$ eosinophilia). Post-allergen challenge eosinophils expressed IL-5 and GM-CSF mRNA, but did not express IL-1 $\boldsymbol{\beta}$ or IL-2 mRNA. To determine whether the IL-5 mRNA-positive cells coexpressed GM-CSF mRNA, double mRNA labeling experiments with a digoxigenin-11-UTP nonradioactive labeled IL-5 RNA probe and a GM-CSF ${ }^{35}$ S-labeled RNA probe were performed. These studies demonstrated that individual eosinophils expressed one of four cytokine mRNA profiles ( $\mathrm{IL-5}^{+}$, GM-

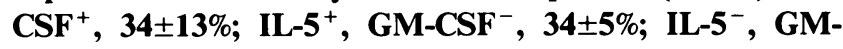

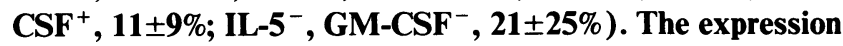
of IL-5 and GM-CSF by eosinophils at sites of allergic inflammation in asthmatics may provide an important autocrine pathway, maintaining the viability and effector function of the recruited eosinophils. (J. Clin. Invest. 1992.90:1414-1424.) Key words: asthma • eosinophil • interleukin 5 • granulocyte macrophage-colony-stimulating factor $\bullet$ in situ hybridization
\end{abstract}

\section{Introduction}

IL-5 (1) and granulocyte macrophage-colony-stimulating factor $(\mathrm{GM}-\mathrm{CSF})^{1}(2)$ are important regulators of eosinophil proliferation and effector function. The ability of these cytokines to maintain the viability and effector function of eosinophils might be important to the pathogenesis of asthma (3). We

This work was presented in part at the Eighth International Congress of Immunology, Budapest, Hungary, 23-28 August 1992.

Address correspondence to Dr. David H. Broide, University of California, San Diego Medical Center, 8417, 225 Dickinson Street, San Diego, CA 92103.

Received for publication 29 January 1992 and in revised form 17 June 1992.

1. Abbreviations used in this paper: $\mathrm{BAL}$, bronchoalveolar lavage; $\mathrm{FEV}_{1}$, forced expiratory volume; GM-CSF, granulocyte macrophagecolony-stimulating factor.

J. Clin. Invest.

(C) The American Society for Clinical Investigation, Inc.

$0021-9738 / 92 / 10 / 1414 / 11 \quad \$ 2.00$

Volume 90, October 1992, 1414-1424 recently showed that immunoreactive GM-CSF is generated in the airway of asthmatics after endobronchial allergen challenge (4). In addition, in situ hybridization demonstrated that GMCSF mRNA positive cells were present in the airway $24 \mathrm{~h}$ after allergen challenge (4). While in situ hybridization is a powerful investigative technique to demonstrate mRNA-positive cells in the airway, unless coupled with additional staining techniques to characterize individual cell types, the identity of the mRNApositive cell cannot be determined. Using combined in situ hybridization and immunostaining for memory $T$ cells (4), we have previously determined that the cellular source of GMCSF mRNA is derived from both a UCHL-1-positive memory $\mathrm{T}$ cell population as well as a UCHL-1-negative cell population. On the basis of adherence experiments, we observed that alveolar macrophages were a significant source of GM-CSF mRNA in the UCHL-1-negative cell population (4). Recent studies demonstrating that peripheral blood eosinophils $(5,6)$ and nasal polyp eosinophils (7) express GM-CSF mRNA led us to investigate whether eosinophils in asthmatic airway express GM-CSF and/or IL-5 mRNA. In particular, we were interested to assess whether eosinophils could account for a subset of the UCHL-1-negative cells expressing GM-CSF mRNA (4). In this study we have combined in situ hybridization with an eosinophil-specific stain to ascertain whether eosinophils express cytokine mRNA (GM-CSF, IL-5) in the airway of asthmatics after endobronchial allergen challenge. In selected experiments we used double mRNA labeling techniques (radioactive GM-CSF and nonradioactive IL-5 RNA probes) to determine at a single cell level whether individual IL-5 mRNA-positive cells coexpress GM-CSF mRNA.

\section{Methods}

Study subjects. Atopic asthmatics with a current history of wheezing on exposure to cats, grass pollen, or house dust mite were recruited for study in a protocol approved by the University of California, San Diego, (UCSD) Human Subjects Committee. Study subjects who required medications other than inhalation beta agonists and antihistamines to adequately control symptoms of asthma and associated allergic rhinitis were not enrolled into the study. Laboratory confirmation of respiratory allergy to cats, grass pollen, or house dust mite was demonstrated using immediate hypersensitivity skin tests and inhalation allergen challenge as previously described in detail (4). The study subjects had a history and physical examination, baseline spirometry, immediate hypersensitivity skin tests, and methacholine challenge performed at visit one, diluent inhalation challenge at visit two, inhalation allergen challenge at visit three, and endobronchial allergen challenge at visit four. Only subjects who had both an immediate ( $>20 \%$ decrease in forced expiratory volume $\left.\left[\mathrm{FEV}_{1}\right]\right)$ as well as a late phase response ( $>15 \%$ decrease in $\mathrm{FEV}_{1} 2-8 \mathrm{~h}$ later) to inhalation allergen challenge (at visit three), underwent endobronchial allergen challenge with an allergen concentration equal to $10 \%$ of the $\mathrm{PD}_{20} \mathrm{FEV}_{1}$ concentration (the concentration of inhaled allergen at visit three that caused a 20\% decrease in $\mathrm{FEV}_{1}$ ). No subjects who had either spontaneous immediate $\left(>10 \%\right.$ decrease in $\left.\mathrm{FEV}_{1}\right)$ or spontaneous late phase re- 
Table I. Asthma Study Subjects

\begin{tabular}{|c|c|c|c|c|c|}
\hline $\begin{array}{c}\text { Study } \\
\text { subject }\end{array}$ & Age & Sex & $\begin{array}{l}\text { Baseline } \\
\text { FEV }_{1}\end{array}$ & $\frac{\text { Methacholine }}{\mathrm{PC}_{20}{ }^{*}}$ & Allergen $n^{\ddagger}$ \\
\hline & $y r$ & $M / F$ & $\begin{array}{c}\text { Percent } \\
\text { predicted }\end{array}$ & $m g / m l$ & \\
\hline 1 & 21 & $\mathbf{M}$ & 80 & 5.0 & Cat \\
\hline 2 & 44 & $\mathbf{M}$ & 73 & 6.0 & Cat \\
\hline 3 & 22 & $\mathbf{M}$ & 97 & 0.6 & Grass pollen \\
\hline 4 & 18 & $F$ & 92 & 2.5 & Cat \\
\hline 5 & 23 & $\mathbf{M}$ & 91 & 0.6 & House dust mite \\
\hline $\begin{array}{l}\text { Mean } \\
+ \text { SEM }\end{array}$ & $25.6 \pm 10.5$ & $\begin{array}{l}4 \mathrm{M} \\
\mathrm{IF}\end{array}$ & $87 \pm 10 \%$ & $\begin{array}{c}2.9 \pm 2.5 \\
\mathrm{mg} / \mathrm{ml}\end{array}$ & \\
\hline
\end{tabular}

*A methacholine $\mathrm{PC}_{20}<8 \mathrm{mg} / \mathrm{ml}$ is characteristic of asthmatics (11). ${ }^{\ddagger}$ The house dust mite allergen used was Dermatophagoides pteronyssinus (4). The subject challenged with grass pollen (fescue) was challenged out of season.

sponses ( $>10 \%$ decrease $\mathrm{FEV}_{1}$ 2-8 $\mathrm{h}$ after inhalation of diluent) were included in the study.

Endobronchial allergen challenge. Endobronchial allergen challenge was performed at least $2 \mathrm{wk}$, and in most cases 4-6 wk after inhalation allergen challenge. Subjects (admitted to the UCSD Clinical Research Center) were premedicated with atropine $0.6 \mathrm{mg}$ intramuscularly and received supplemental $\mathrm{O}_{2}$ during the bronchoscopy. Topical anesthesia of the upper and lower airways was achieved with $0.45 \%$ tetracaine. A pre-allergen challenge bronchoalveolar lavage (BAL) with a total volume of $100 \mathrm{ml}$ sterile $37^{\circ} \mathrm{C}$ normal saline was used to lavage the right middle lobe using a flexible bronchoscope (model 19D; Pentax Precision Instruments Corp., Orangeburg, NY). This was followed by installation of $1 \mathrm{ml}$ of a $10 \%$ solution ( $\mathrm{vol} / \mathrm{vol}$ ) of the $\mathrm{PD}_{20}$ $\mathrm{FEV}_{1}$ concentration of allergen (as determined at the inhalation allergen visit) into the posterior segment of the right lower lobe, and $1 \mathrm{ml}$ of diluent (negative control) instilled into the anterior segment of the right lower lobe. A repeat bronchoscopy with $100 \mathrm{ml}$ saline lavage in both the right lower lobe posterior segment (site of allergen challenge) and right lower lobe anterior segment ( site of control diluent challenge) was performed $24 \mathrm{~h}$ after the endobronchial instillation of allergen or diluent. BAL samples were aspirated with gentle suction, collected in polyethylene tubes on ice, passed through a single layer of gauze, and processed immediately to separate cells from the lavage fluid by centrifugation at $300 \mathrm{~g}$ for $10 \mathrm{~min}$ at $4^{\circ} \mathrm{C}$. Cells pelleted by centrifugation were resuspended in buffered PBS to $2 \times 10^{5}$ cells $/ \mathrm{ml}$ and a $100-\mu l$ aliquot of this suspension was used to prepare a set of cytocentrifuge slides by spinning the aliquots at $450 \mathrm{rpm}$ for $4 \mathrm{~min}$ in a cytospin (Shandon Inc., Pittsburgh, PA). After air drying, slides were either Wright-Giemsa stained for cell differential counts, fixed in acetone for $4 \mathrm{~min}$ and stored at $-70^{\circ} \mathrm{C}$ before immunocytochemistry, or fixed in $4 \%$ paraformaldehyde for $4 \mathrm{~min}$ at room temperature and stored in $70 \%$ ethanol at $4^{\circ} \mathrm{C}$ before in situ hybridization.

In situ hybridization. In situ hybridization with ${ }^{35} \mathrm{~S}$-labeled single stranded IL-5, GM-CSF, IL- $1 \beta$, or IL- 2 sense or antisense RNA probes was performed as previously described in this laboratory $(4,8)$. IL-1 $\beta$ and IL-2 probes were kindly provided by Cetus Corporation, Emoryville, CA. The GM-CSF probe was kindly provided by Dr. Ken Kauschansky, University of Washington, Seattle, WA. The 345-bp human IL-5 cDNA (BBG 16) was purchased from R + D Systems, Minneapolis, MN. It was subcloned into the HindIII EcoRI site of PGEM 1 before use in in situ hybridization experiments. The identity and orientation of the IL-5 probe was confirmed by restriction endonuclease mapping. In situ hybridized slides were counterstained with hematoxylin, permanently mounted, and coded. For each postallergen slide, the number of grains over the cytoplasm of 400 individual cells was deter- mined by counting 100 cells in each of four randomly selected fields. As the number of eosinophils on pre-allergen challenge slides $(0.6 \pm 0.5 \%)$ was considerably less than on post-allergen challenge slides $(48.2 \pm 25.6 \%$ ), fewer eosinophils (a minimum of 50 eosinophils per subject) were evaluated on preallergen slides. Cells were considered positive for cytokine mRNA if $>10$ grains were localized over the cytoplasm.

Control experiments performed to exclude nonspecific hybridization of antisense RNA probes to eosinophils, included the use of sense probes, and pretreatment of slides to be hybridized with RNase ( 10 $\mu \mathrm{g} / \mathrm{ml}$ in $2 \times$ standard saline citrate [SSC]) for $30 \mathrm{~min}$ at $37^{\circ} \mathrm{C}$ before hybridization. In addition, all in situ hybridization experiments were performed under conditions of high stringency to prevent nonspecific hybridization.

Dual cytokine $m R N A$ detection. Detection of dual cytokine mRNA expression in single experiments used methods previously described in this laboratory (9) and detailed below.

Probe preparation. To determine whether individual IL-5 mRNApositive cells coexpressed GM-CSF mRNA, single experiments were performed with both a nonradioactive IL-5 RNA probe and an ${ }^{35} \mathrm{~S}$-labeled GM-CSF RNA probe. IL-5 cDNA was nonradioactively labeled with digoxigenin-11-UTP. An enzyme-linked color reaction (Vector red; Vector Laboratories, Burlingame, CA) identified cells that hybridized to the nonradioactive digoxigenin-11-UTP IL-5 RNA probe.

Incorporation of the nucleotide analogue (digoxigenin-11-UTP) into an IL-5 RNA probe was performed as previously described (9). 2 $\mu \mathrm{g}$ of linearized IL- 5 template was incubated at $37^{\circ}$ for $2 \mathrm{~h}$ in $20 \mu \mathrm{l}$ final reaction vol containing $5 \times$ transcription buffer, unlabeled CTP, ATP, GTP, 20 mM DTT, RNase inhibitor, RNA polymerase (T7 or SP6), and digoxigenin-11-UTP. The amount of nonradioactive IL-5 RNA probe generated was quantified on a $1 \%$ agarose gel using tRNA standards. ${ }^{35}$ S-radiolabeled antisense and sense RNA probes were produced as previously described, using ${ }^{35}$ S-UTP (Amersham Corp., Arlington Heights, IL) (9).

Hybridization and washes. Cytospun slides were fixed in paraformaldehyde, incubated for $30 \mathrm{~min}$ at $37^{\circ} \mathrm{C}$ in $10 \mathrm{mM}$ iodoacetamide, 10 $\mathrm{mM} N$-ethylmaleimide, and than acetylated. The slides were then incubated in $0.1 \mathrm{M}$ glycine, $0.2 \mathrm{M}$ Tris- $\mathrm{HCl}, \mathrm{pH} 7.4$, and prehybridized as previously described $(4,8,9)$. The hybridization mixture $(2 \times$ SSC, $50 \%$ formamide, $1 \mathrm{mg} / \mathrm{ml} \mathrm{tRNA}, 2 \mathrm{mg} / \mathrm{ml} \mathrm{BSA}, 1 \mathrm{mg} / \mathrm{ml} \mathrm{DNA}, 10$ $\mathrm{mg} / \mathrm{ml}$ polyethylene glycol, $10 \mathrm{mM}$ DTT, and $0.5 \times 10^{5} \mathrm{cpm} / \mu \mathrm{l}$ of ${ }^{35} \mathrm{~S}$-labeled cytokine probe and/or $100 \mathrm{ng}$ of digoxigenin-11-UTP-labeled IL- 5 probe) was heated at $80^{\circ} \mathrm{C}$ for 5 min, placed on the slides, covered with a coverslip, and sealed with rubber cement. Slides were hybridized in a humidified chamber overnight at $50^{\circ} \mathrm{C}$. Coverslips were then removed and the slides washed in $2 \times$ SSC followed by 2 $\times \mathrm{SSC}, 50 \%$ formamide at $50^{\circ} \mathrm{C}$. Unhybridized probes were digested in $50 \mu \mathrm{g} / \mathrm{ml} \mathrm{RNase} \mathrm{A,} 500 \mathrm{mM} \mathrm{NaCl}, 1 \mathrm{mM}$ EDTA, and $30 \mathrm{mM}$ Tris $\mathrm{HCl}$ $\mathrm{pH} 7.5$ for $30 \mathrm{~min}$ at $37^{\circ} \mathrm{C}$. The slides were then washed in $2 \times \mathrm{SSC}$, $50 \%$ formamide at $50^{\circ} \mathrm{C}$, followed by three washes in $2 \times \mathrm{SSC}$ at room temperature.

Alkaline phosphatase and autoradiography. Slides were incubated in $150 \mathrm{mM} \mathrm{NaCl}, 0.1 \mathrm{M}$ Tris, $\mathrm{pH} 7.5$, and $0.1 \% \mathrm{BSA}$ (wash buffer) for 5 min followed by wash buffer plus $0.5 \%$ blocking agent (Boehringer Mannheim Corp., Indianapolis, IN) for $30 \mathrm{~min}$ at room temperature. The slides were blocked with $10 \%$ rabbit serum followed by $10 \%$ human $\mathrm{AB}$ serum and then incubated with the mouse antidigoxin antibody (Sigma Chemical Co., St. Louis, MO.) in $2 \%$ rabbit serum and $2 \%$ human $\mathrm{AB}$ serum for $1 \mathrm{~h}$ at $37^{\circ} \mathrm{C}$. After washing three times, biotinylated rabbit Fab anti-mouse IgG was added for $30 \mathrm{~min}$ at room temperature. The slides were then washed and incubated with $0.3 \%$ BSA in wash buffer followed by alkaline phosphatase-streptaviden (Dako Corp., Carpenteria, CA) for $30 \mathrm{~min}$. Alkaline phosphatase was developed using a red dye substrate kit (Vector Laboratories). The slides were washed and dehydrated in graded ethanol washes. After drying, the slides were dipped in Kodak NTB-2 emulsion diluted 1:1 with 600 $\mathrm{mM}$ ammonium acetate. The slides were developed after three days in Kodak D19 developer, counterstained with hematoxylin, and exam- 


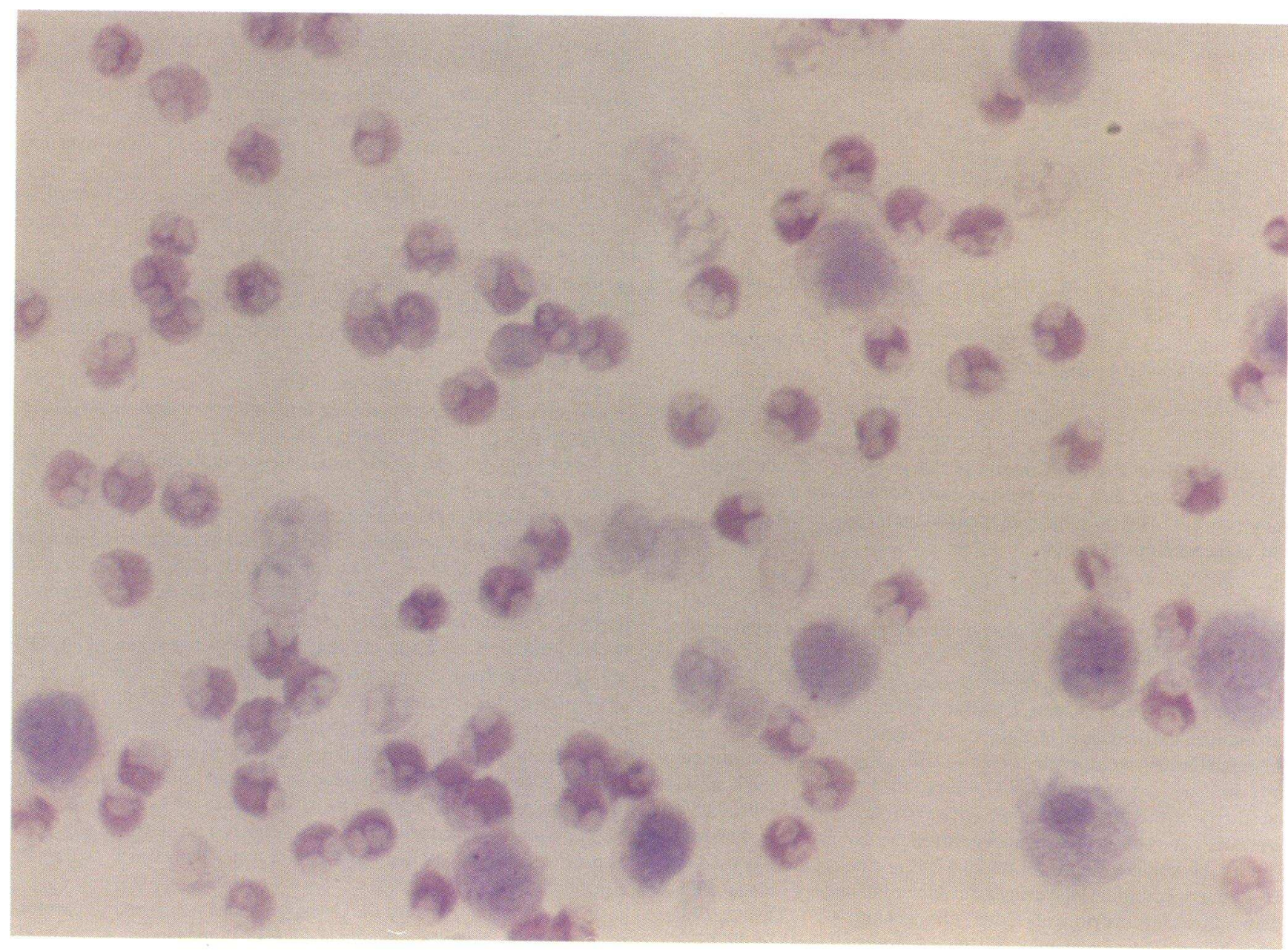

Figure 1. Postallergen BAL cells stained with chromotrope 2R. BAL cells were stained with hematoxylin and carbol chromotrope 2R. A large number of eosinophils with red cytoplasm (carbol chromotrope positive) and bilobed nuclei are evident. Hematoxylin stains nuclei of mononuclear cells. Note that carbol chromotrope 2R does not stain other cells present in BAL fluid. Magnification, 400.

ined by light- and dark-field microscopy. Cells staining red after development with alkaline phosphatase substrate were considered to express IL-5 mRNA. Nonspecific color reactions were excluded by use of the control sense IL-5 RNA probe in all experiments. Cells hybridizing to the ${ }^{35}$ S-labeled RNA probe in experiments using radioactive and nonradioactive RNA probes were evaluated as described above for in situ hybridization with only an ${ }^{35}$ S-labeled RNA probe.

Eosinophil staining. ${ }^{35} \mathrm{~S}$-labeled in situ hybridization slides were counterstained for $1 \mathrm{~h}$ with $1 \%$ carbol chromotrope 2R (Roboz Surgical Instrument Co., Inc., Washington, DC) (10) in preference to eosin, as carbol chromotrope $2 \mathrm{R}$ produces superior staining of eosinophils in paraformaldehyde-fixed cells processed by in situ hybridization.

GM-CSF immunocytochemistry. GM-CSF immunocytochemistry was performed with a mouse monoclonal anti-human GM-CSF antibody (Genzyme Corp., Boston, MA) and a control species and isotype specific $\mathrm{IgG}_{1}$ antibody using the immunoperoxidase method as previously described in this laboratory (4).

Statistics. Statistical analysis was performed using the Student's $t$ test.

\section{Results}

Asthma study subjects (Table I). The asthma study subjects comprised four males and one female. They were all atopic and had mild asthma, as evidenced by a baseline $\mathrm{FEV}_{1}$ of $3.78 \pm 0.73$ liters $\left(87 \pm 10 \%\right.$ of predicted $\left.F E V_{1}\right)$. The concentra- tion of methacholine that caused a $20 \%$ decrease in $\mathrm{FEV}_{1}\left(\mathrm{PC}_{20}\right.$ $\left.\mathrm{FEV}_{1}\right)$ ranged from 0.6 to $6.0 \mathrm{mg} / \mathrm{ml}(2.9 \pm 2.5 \mathrm{mg} / \mathrm{ml})$. The $\mathrm{PD}_{20}$ concentration of allergen was $11.2 \pm 12.7$ inhalation $\mathrm{U}$ (range 0.5-25 inhalation U) (11).

Bronchoalveolar cells. The lavage volume recovered preallergen challenge $(57 \pm 3 \mathrm{ml})$ did not differ significantly from that recovered post-allergen challenge $(42 \pm 14 \mathrm{ml})$. There was a significant increase in the percentage of eosinophils in the allergen challenge lung segment (Fig. 1), $24 \mathrm{~h}$ post-compared to pre-allergen challenge $(48.2 \pm 25.6 \%$ vs $0.6 \pm 0.5 \%)$ ( $P$ $=0.05)$. In contrast, the diluent challenge elicited no significant eosinophil response $(0.8 \pm 0.4 \%$ eosinophils $)$.

$I L-5$ and GM-CSF $m R N A$ expression. Allergen challenge induced a significant number of eosinophils to express IL-5 and GM-CSF mRNA $24 \mathrm{~h}$ post-allergen challenge (Table II, Figs. 2-6). The recognition of eosinophils expressing IL-5 and GM-CSF mRNA was facilitated by identifying cells with bilobed nuclei (characteristic of eosinophils) (Figs. 1 and 2), and definitively by staining with carbol chromotrope $2 \mathrm{R}$ (Figs. 3-5). Eosinophils were the only pre- or post-allergen challenge BAL cells to stain with carbol chromotrope 2R (Fig. 1). Eosinophils were not the only cells expressing GM-CSF or IL-5 mRNA. As indicated in Figs. 4 and 6, mononuclear cells were also a significant source of IL-5 and GM-CSF mRNA. Control 
Table II. Percent BAL Eosinophils Expressing Cytokine mRNA

\begin{tabular}{ccc}
\hline & \multicolumn{2}{c}{ Percent eosinophils mRNA } \\
\cline { 2 - 3 } 3sS Antisense RNA probe & Negative & Positive \\
\hline & \multicolumn{2}{c}{$\%$} \\
IL-1 & 99 & $<1$ \\
IL-2 & 99 & $<1$ \\
IL-5 & $31 \pm 19$ & $69 \pm 19$ \\
GM-CSF & $55 \pm 26$ & $45 \pm 26$ \\
\hline
\end{tabular}

Post-allergen challenge BAL cells $(n=5)$ were hybridized with ${ }^{35} \mathrm{~S}$ labeled cytokine RNA sense and antisense probes. Eosinophils were identified with carbol chromotrope $2 \mathrm{R}$ staining. In all experiments the control sense ${ }^{35}$ S-labeled cytokine RNA probe hybridized to $<1 \%$ of eosinophils.

The number of eosinophils expressing GM-CSF mRNA ranged from $2.6 \%$ of total BAL cells (in a patient with $22 \%$ BAL eosinophilia) to $54.9 \%$ of total BAL cells (in a patient with $82 \%$ BAL eosinophilia). Similarly in these two patients, the number of eosinophils expressing IL-5 mRNA ranged from 8.4 to $72.2 \%$ of total BAL cells.

There was a significant correlation between the degree of BAL eosinophilia and the proportion of BAL eosinophils that were positive for IL-5 mRNA $(r=0.93)$ and GM-CSF mRNA $(r=0.95)$.

experiments (sense RNA probes, and pretreatment of slides to be hybridized with RNase) excluded nonspecific hybridization of the IL-5 or GM-CSF antisense RNA probe to eosinophils. The control sense ${ }^{35}$ S-labeled IL-5 (Fig. 3) or GM-CSF RNA probe hybridized to $<1 \%$ of pre- or post-allergen challenge BAL cells. Pretreatment of slides to be hybridized with RNase completely inhibited the hybridization of either the IL-5 or GM-CSF antisense RNA probe to eosinophils.

The percentage of pre-allergen challenge BAL eosinophils expressing GM-CSF $(1.2 \pm 0.2 \%)$ and IL-5 $(1.6 \pm 0.4 \%) \mathrm{mRNA}$ was significantly less than the percentage of post-allergen challenge BAL eosinophils expressing GM-CSF $(45 \pm 26 \%)(P$ $=0.003)$ or IL-5 $(69 \pm 19 \%)(P=0.002)$ mRNA (Table II). BAL cells recovered from the diluent challenged lung segment did not express IL-5 or GM-CSF mRNA.

GM-CSF immunocytochemistry. Immunostaining of BAL eosinophils with a monoclonal antibody to GM-CSF revealed that $1.2 \pm 1.1 \%(n=5)$ of pre-allergen and $59 \pm 27 \%(n=5)$ of post-allergen challenge BAL eosinophils immunostain positively for GM-CSF (Fig. $7 \mathrm{~A}$ ). No staining of BAL eosinophils was observed with a negative control species and isotype-specific $\mathrm{IgG}_{1}$ antibody (Fig. $7 \mathrm{~B}$ ).

$I L-1 \beta$ and $I L-2$ mRNA expression. To determine whether eosinophils expressed a restricted or unrestricted cytokine mRNA profile, BAL cells were hybridized with IL- $1 \beta$ and IL-2 ${ }^{35}$ S-labeled sense and antisense RNA probes. Eosinophils did not hybridize to either of these RNA probes. In control in situ hybridization experiments, stimulated alveolar macrophages (IL-1 $\beta$ ) and T cell clones (IL-2) hybridized to the respective cytokine antisense RNA probe (data not shown).

$I L-5$ nonradioactive $R N A$ probe. The ${ }^{35} \mathrm{~S}$-labeled (Fig. 2) and the digoxigenin-11-UTP-labeled (Fig. 5) IL-5 antisense RNA probes detected approximately equivalent numbers of IL-5 mRNA positive eosinophils. The control sense digoxigenin-1 1-UTP-labeled IL-5 probe hybridized to $<1 \%$ of eosinophils (Fig. 5 B). The ${ }^{35}$ S-labeled IL-5 antisense RNA probe is more sensitive than the digoxigenin-11-UTP IL-5 antisense RNA probe in hybridizing to low levels of IL-5 mRNA. However, as the majority of eosinophils strongly expressed IL-5 mRNA (Figs. 2 and 5), this allowed us to use a nonradioactive IL-5 probe in dual cytokine mRNA detection experiments.

Dual cytokine $m R N A$ labeling. To determine whether the IL-5 mRNA positive cells coexpressed GM-CSF mRNA, double mRNA labeling experiments with a nonradioactive digoxigenin-1 1-UTP-labeled IL-5 RNA probe and a ${ }^{35}$ S-labeled GMCSF RNA probe were performed. These studies showed that individual eosinophils expressed one of four cytokine mRNA

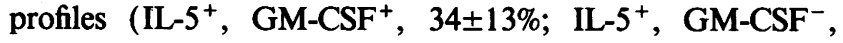
$34 \pm 5 \%$; IL-5-, GM-CSF $^{+}, 11 \pm 9 \%$; IL-5 ${ }^{-}$, GM-CSF$^{-}$, $21 \pm 25 \%$ ) (Fig. 6). In addition, mononuclear cells also expressed IL-5 (Fig. 6) and GM-CSF mRNA in these double mRNA-labeling experiments.

\section{Discussion}

Several studies have demonstrated that eosinophils express functional GM-CSF and IL-5 receptors ( 1,2$)$. This study demonstrates that in vivo eosinophils at sites of allergic inflammation in asthmatics express GM-CSF and IL-5 mRNA, raising the possibility that autocrine expression of $\operatorname{GM}-\operatorname{CSF}(5,6)$ and IL- $5^{2}$ by eosinophils might prolong their survival and effector function. Whereas unstimulated peripheral blood eosinophils do not express GM-CSF mRNA, eosinophils stimulated in vitro with either the calcium ionophore $\mathrm{A} 23187$ or gamma interferon express GM-CSF mRNA (6). In addition, in vitrostimulated eosinophils express GM-CSF protein as assessed by immunostaining of eosinophils (6) as well as measuring bioactive GM-CSF in ionomycin/phorbol myristate acetate-stimulated eosinophil supernatants (5). Determining whether eosinophils in asthmatic airway express GM-CSF protein in vivo is problematic when using either immunostaining of eosinophils or BAL fluid GM-CSF analysis. As eosinophils express functional GM-CSF receptors, eosinophils that immunostain positively for GM-CSF could either be synthesizing GM-CSF or have cell surface GM-CSF receptors occupied by GM-CSF synthesized by another cell type. Similarly, analysis of immunoreactive GM-CSF levels in BAL fluid (which we have previously shown to increase significantly post-allergen challenge) (4) would not be able to identify the eosinophil as the cellular source of the immunoreactive GM-CSF. Thus, this study extends our previous observation that memory $T$ cells and alveolar macrophages express GM-CSF mRNA to include eosinophils as an additional source of GM-CSF mRNA. As this study has used BAL cells and not bronchial mucosal biopsies, it is still possible that other cell types including tissue mast cells, epithelial cells, endothelial cells, and/or fibroblasts in the bronchial mucosa, could express GM-CSF mRNA after allergen challenge. In this regard it is of interest that as yet uncharacterized cells in mucosal biopsies from mildly symptomatic asthmatics express IL-5 mRNA (13).

This study also provides evidence that eosinophils in asthmatic airway express IL-5 mRNA. Again the eosinophil is not the only cell type in the airway to express IL- 5 mRNA, as

2. While this manuscript was in review, IL-5 mRNA expression by eosinophils in patients with coeliac disease was reported (12). 

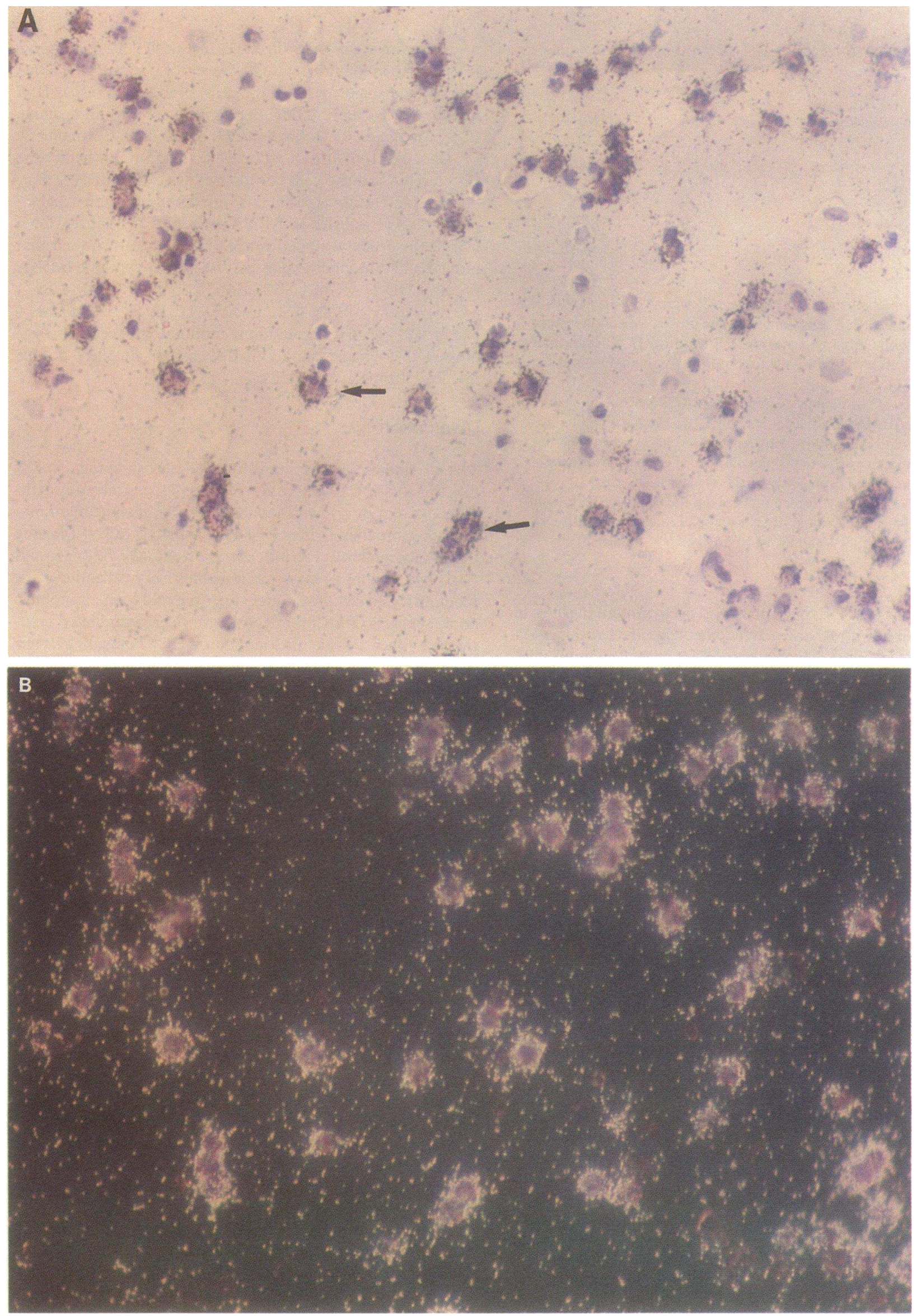

Figure 2. BAL eosinophils express IL-5 mRNA. Post-allergen challenge BAL cells were in situ hybridized with a ${ }^{35} \mathrm{~S}-$ labeled IL-5 antisense probe and counterstained with carbol chromotrope $2 \mathrm{R}$ to identify eosinophils (red stain). Clusters of silver grains over the cytoplasm identify cells expressing IL-5 mRNA. A closed arrow identifies one of many eosinophils (carbol chromotrope positive) expressing IL-5 mRNA. Hematoxylin stains bilobed nuclei of eosinophils and single lobed nuclei of mononuclear cells. $(A)$ Light-field and $(B)$ dark-field view of the same photographic field. Magnification, 200. 

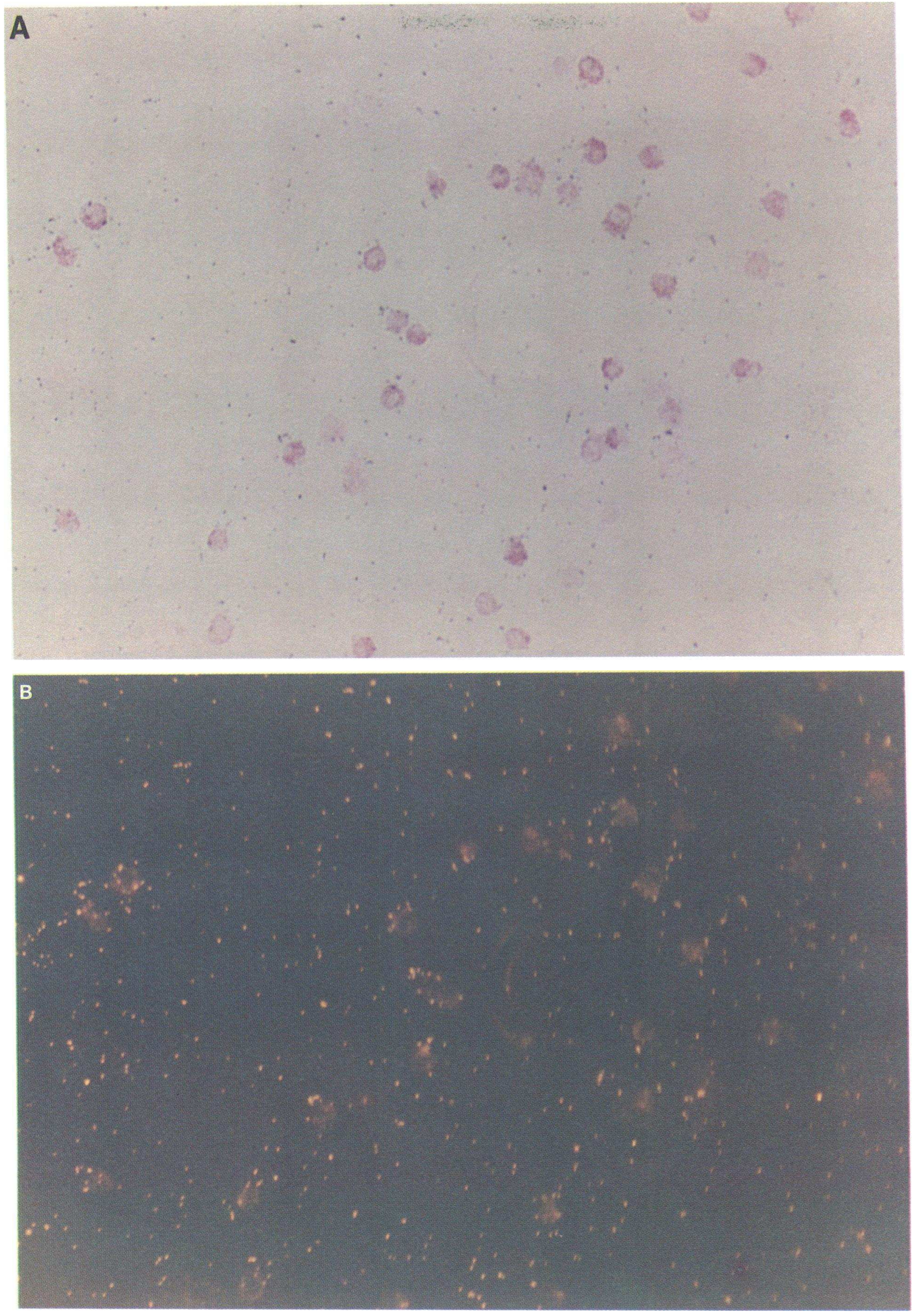

Figure 3. Post-allergen challenge BAL cells in situ hybridized with ${ }^{35}$ S-labeled IL-5 sense RNA probe. Carbol chromatrope 2 R stain demonstrates characteristic cytoplasmic granules (red) of BAL eosinophils. Note that carbol chromotrope $2 \mathrm{R}$ does not stain other cells present in BAL fluid. $(A)$ Light-field and $(B)$ dark-field view of the same photographic field, demonstrating absence of hybridization to the control ${ }^{35}$ S-labeled IL-5 sense RNA probe. No hematoxylin stain was used in this figure and therefore mononuclear cells are not visualized. Magnification, 400. 

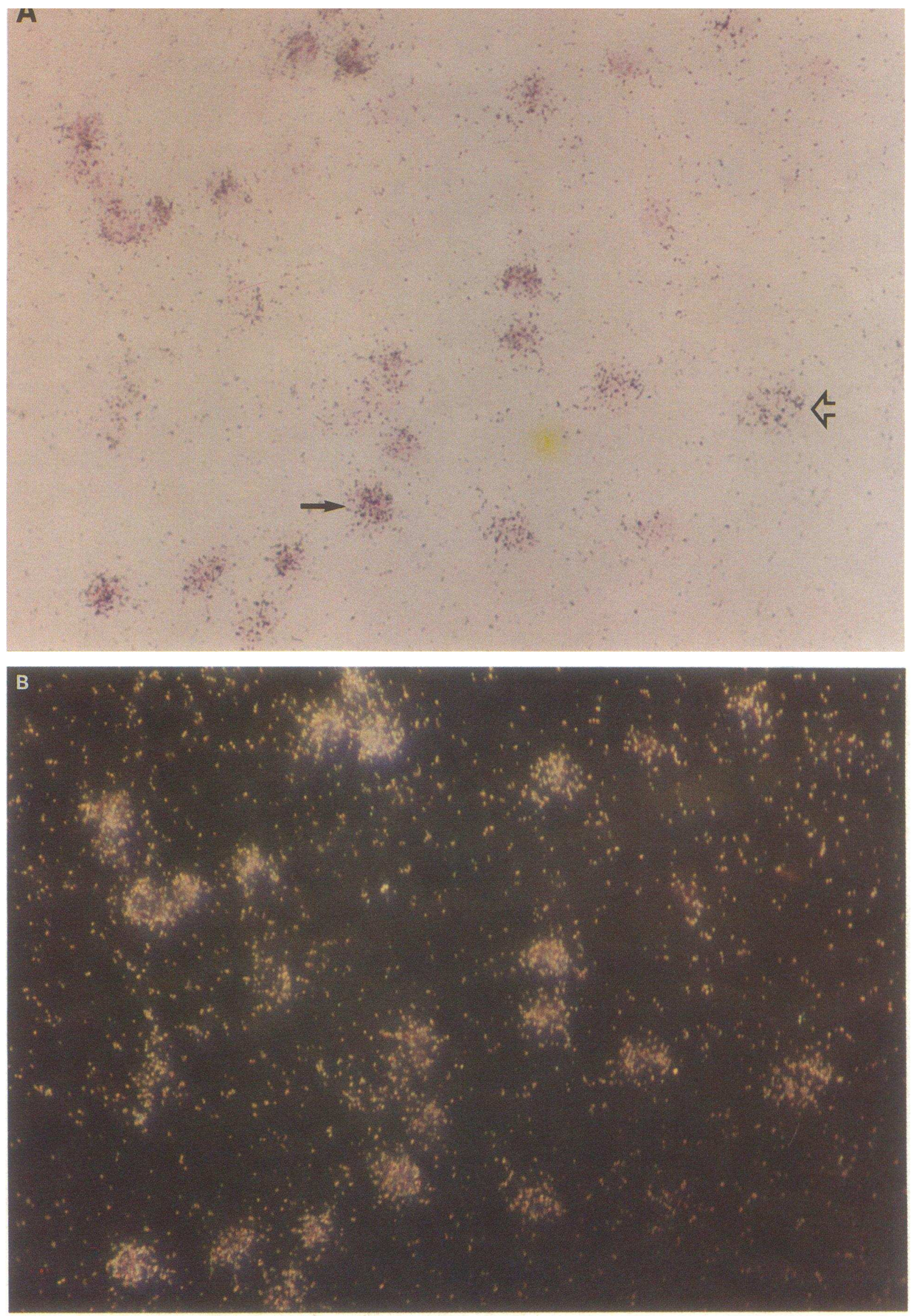

Figure 4. BAL Eosinophils express GM-CSF mRNA. Post-allergen challenge BAL cells were in situ hybridized with a ${ }^{35}$ S-labeled GM-CSF antisense probe and counterstained with carbol chromotrope $2 \mathrm{R}$ to identify eosinophils. A closed arrow identifies a carbol chromotrope positive eosinophil expressing GM-CSF mRNA. An open arrow indicates a carbol chromotrope negative cell which also expresses GM-CSF mRNA. As the combination of a strong hybridization signal and hematoxylin staining can obscure the carbol chromotrope staining of eosinophils, no hematoxylin stain is used in this figure. $(A)$ Light-field and $(B)$ dark-field view of the same photographic field. Magnification, 400. 
A

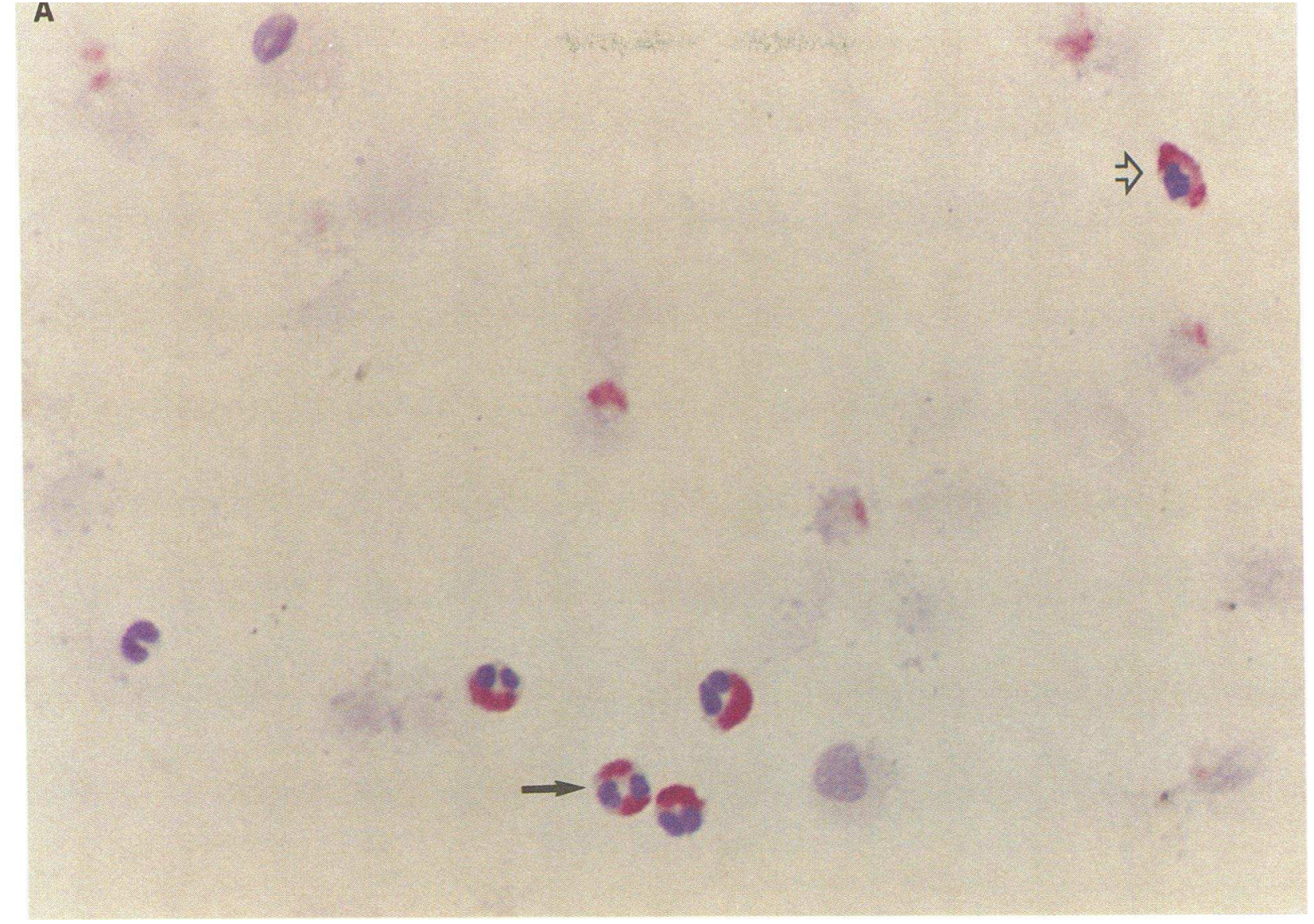

B
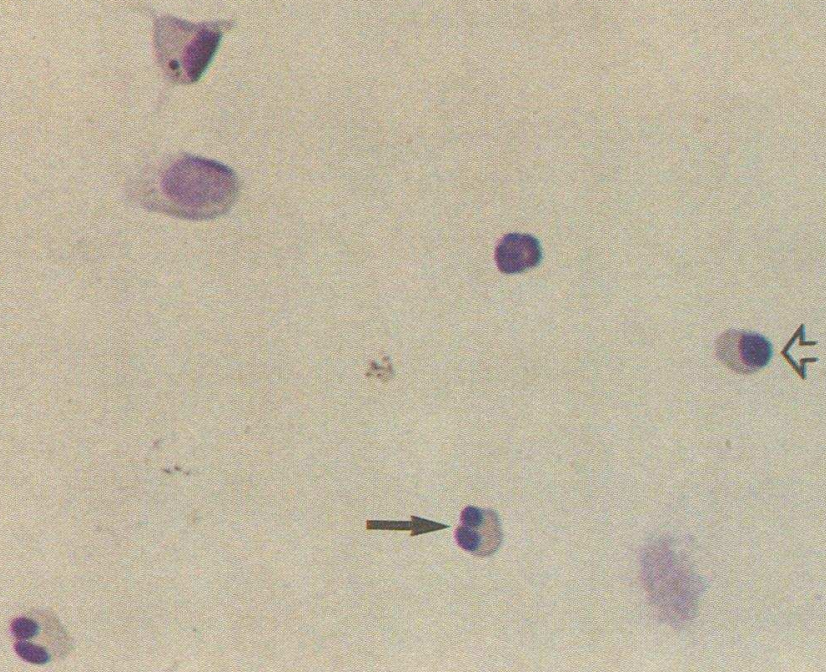

Figure 5. Detection of IL-5 mRNA using a nonradioactive IL-5 probe. Post-allergen challenge BAL cells were in situ hybridized with a digoxigen-1 1-UTP-labeled IL-5 RNA probe. An enzyme-linked color reaction (Vector red; Vector Laboratories) identifies cells hybridizing to the nonradioactive IL-5 RNA probe. Eosinophils (closed arrow) and a mononuclear cell (open arrow) hybridizing to the IL-5 antisense probe are indicated in $A$. In $B$, eosinophils (closed arrow) and mononuclear cells (open arrow) do not hybridize to the control sense probe. Cells with bilobed nuclei ( see Figs. 1 and 2) are identifiable as eosinophils. Hematoxylin stains all nuclei purple. Magnification, 400. 

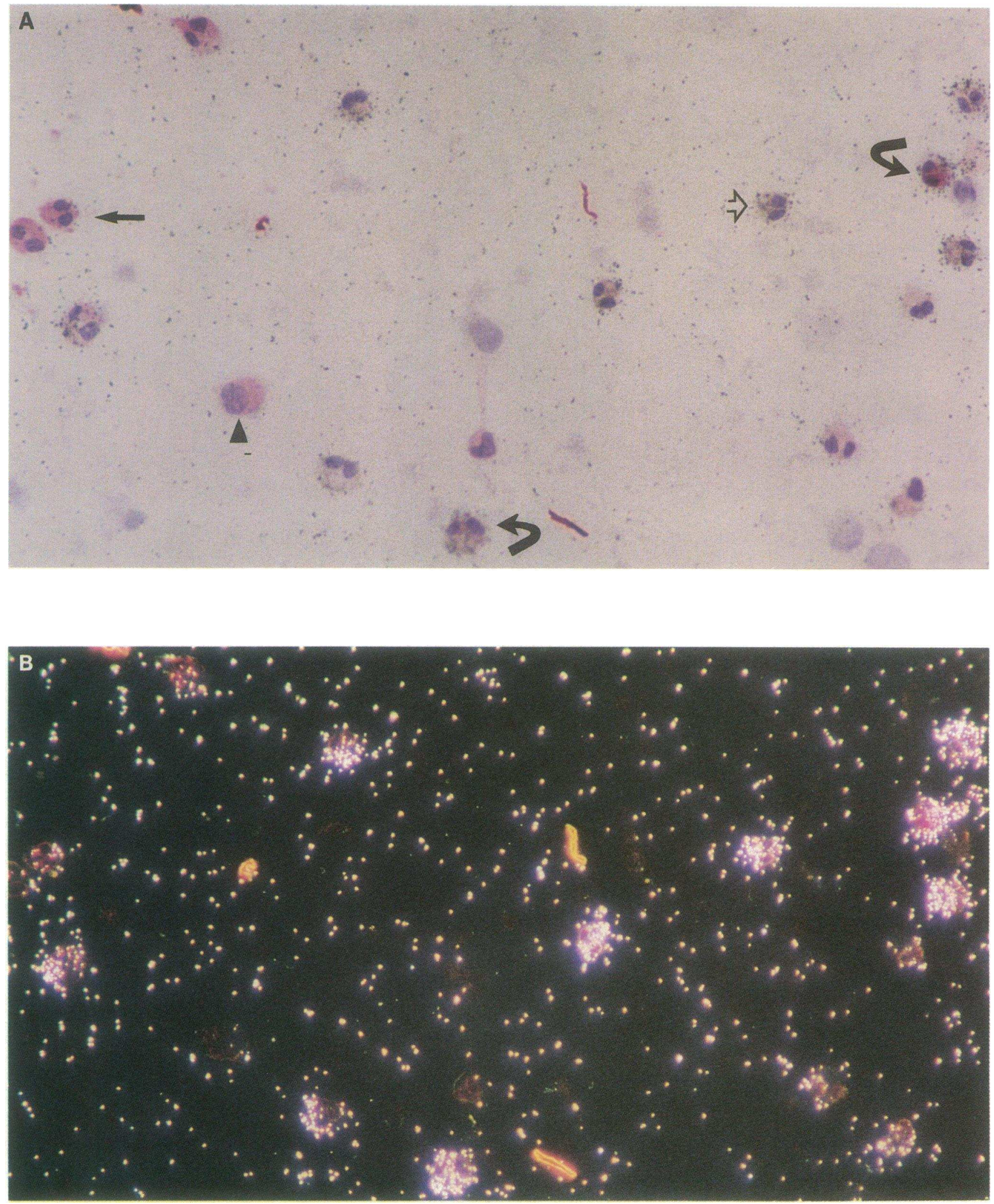

Figure 6. Dual cytokine mRNA detection in single cells. Post-allergen challenge BAL cells were in situ hybridized with both an IL-5 antisense probe (digoxigen-11-UTP-labeled) and a GM-CSF antisense probe $\left({ }^{35} \mathrm{~S}\right.$-labeled). Eosinophils expressing both IL-5 and GM-CSF mRNA are indicated with a curved arrow. Some eosinophils express either IL-5 mRNA (closed arrow) or GM-CSF mRNA (open arrow). A mononuclear cell expressing IL-5 mRNA (small black triangle) is also indicated. Hematoxylin counterstains all nuclei purple. $(A)$ Light-field and $(B)$ darkfield view of the same photographic field. Magnification, 400 . 

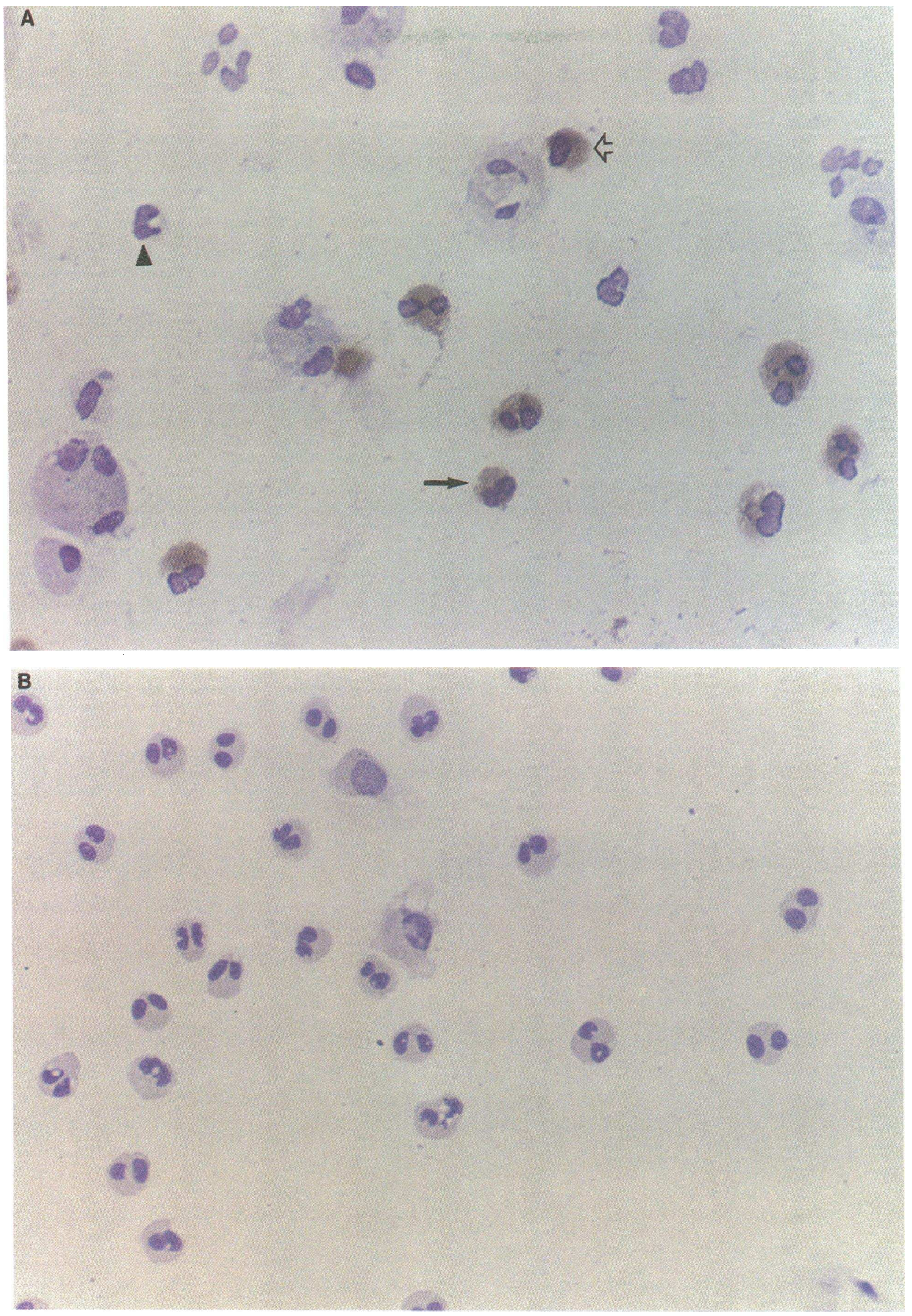

Figure 7. GM-CSF Immunocytochemistry of BAL cells. Post-allergen challenge BAL cells were immunostained with a mouse monoclonal anti-human GM-CSF antibody $(A)$ or control species and isotype-specific $\mathrm{IgG}_{1}$ antibody $(B)$ using the immunoperoxidase method. Hematoxylin stains all nuclei purple. Cells that immunostain with the GM-CSF antibody have a brown cytoplasm. The control antibody does not immunostain eosinophils. Both eosinophils (bilobed nuclei) (closed arrow) and mononuclear cells (open arrow) stain with the GM-CSF antibody. Not all eosinophils ( small black triangle) stain with the GM-CSF antibody. Magnification, 400. 
mononuclear cells were also positive. The demonstration that multiple cell types express GM-CSF and IL-5 mRNA after allergen stimulation raises important questions when evaluating whether individual cells or cell types express cytokine profiles unique to allergic inflammation (14). To address the cytokine profile of individual cells at sites of allergic inflammation, we have used both single and double mRNA-labeling techniques. Studies with single mRNA labeling demonstrated that eosinophils recruited into the airway $24 \mathrm{~h}$ post-allergen challenge expressed GM-CSF and IL-5 mRNA, but did not express IL- $1 \beta$ or IL-2 mRNA. Studies using double mRNA-labeling demonstrated that individual eosinophils expressed one of four cyto-

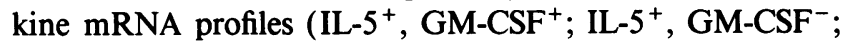

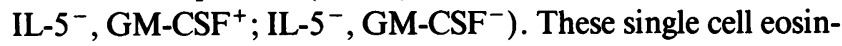
ophil cytokine profiles may reflect different subpopulations of eosinophils (recruited to the airway at different times after allergen stimulation), differences in RNA probe sensitivity (radioactive versus nonradioactive), and/or differences in IL-5 and GM-CSF mRNA stability (15). Future experiments using this double mRNA-labeling technique to study airway cells obtained at various time points after allergen stimulation may provide important insights into assessing whether individual cell types express cytokine profiles unique to allergic inflammation.

\section{Acknowledgments}

We wish to thank Dr. J. Harrell for performing bronchoscopy and bronchoalveolar lavage, Dr. J. Ramsdell and Dr. J. Clausen for use of pulmonary function laboratories, Paul Ferguson and Steve Cooper for assistance with pulmonary function studies, the nurses in the UCSD Clinical Research Center and bronchoscopy units for skilled care of study patients, and Crystal Goodman for her expert secretarial support during the preparation of this manuscript. We gratefully acknowledge helpful discussions with Dr. Stephen I. Wasserman during the course of these studies.

This work was supported by National Institutes of Health grants AI 29974 ( to D. H. Broide), AR 39576 and AR 40525 (to G. S. Firestein), an Asthma and Allergic Disease Center grant (AI 31595), and by the UCSD General Clinical Research Center grant M01 RR00827 from the National Institutes of Health.

\section{References}

1. Lopez, A. F., C. J. Sanderson, J. R. Gamble, H. D. Campbell, I. G. Young, and M. A. Vadas. 1988. Recombinant human interleukin-5 is a selective activator of human eosinophil function. J. Exp. Med. 167:219-224.

2. Silberstein, D. S., W. F. Owen, J. C. Gasson, J. F. DiPersio, D. W. Golde, J. C. Bina, R. Soberman, K. F. Austen, and J. R. David. 1986. Enhancement of human eosinophil cytotoxicity and leukotriene synthesis by biosynthetic (recombinant) granulocyte-macrophage colony stimulating factor. J. Immunol. 137:3290-3294.

3. Weller, P. F. 1991. The immunobiology of eosinophils. N. Engl. J. Med. 324:1110-1118.

4. Broide, D. H., and G. S. Firestein. 1991. Endobronchial allergen challenge in asthma. Demonstration of cellular source of granulocyte macrophage colony stimulating factor by in situ hybridization. J. Clin. Invest. 88:1048-1053.

5. Kita, H., T. Ohnishe, Y. Okubo, D. Weiler, J. S. Abrams, and G. J. Gleich. 1991. GM-CSF and IL-3 release from human peripheral blood eosinophils and neutrophils. J. Exp. Med. 174:745-748.

6. Moqbel, R., Q. Hamid, S. Ying, J. Barkans, A. Hartnell, A. Tsicopoulos, A. J. Wardlaw, and A. B. Kay. 1991. Expression of mRNA and immunoreactivity for the granulocyte/macrophage-colony stimulating factor (GM-CSF) in activated human eosinophils. J. Exp. Med. 174:749-752.

7. Ohno, I., R. Lea, S. Finotto, J. Marshall, J. Denburg, J. Dolovich, J. Gauldie, and M. Jordana. 1991. Granulocyte/macrophage colony-stimulating factor (GM-CSF) gene expression by eosinophils in nasal polyposis. Am. J. Respir. Cell Mol. Biol. 5:505-510.

8. Firestein, G. S., M. M. Paine, and B. H. Littman. 1991. Gene expression (collagenase, tissue inhibitor of metalloproteinases, complement, and HLA-DR) in rheumatoid arthritis and osteoarthritis synovium. Arthritis Rheum. 34:10941105.

9. Firestein, G. S. and M. M. Paine. 1992. Stromelysin and tissue inhibitor of metalloproteinases (TIMP) gene expression in rheumatoid arthritis synovium. Am. J. Pathol. 140:1309-1314.

10. Lendrum, A. C. 1944. The staining of eosinophil polymorphs and enterochromaffin cells in histological sections. J. Pathol. Bacteriol. 56:441.

11. Spector, S. L. 1989. Allergen inhalation challenge procedures. In Provocative Challenge Procedures. Background and Methodology. S. L. Spector, editor. Futura Publishing Co., Mount Kisco, NY. 293-339.

12. Desreumaux, P., A. Janin, J. F. Colombel, L. Prin, J. Plumas, D. Emilie, G. Torpier, A. Capron, and M. Capron. 1992. Interleukin 5 messenger RNA expression by eosinophils in the intestinal mucosa of patients with coeliac disease. J. Exp. Med. 175:293-296.

13. Hamid, Q., M. Azzawi, S. Ying, R. Moqbel, A. J. Wardlaw, C. J. Corrigan, B. Bradley, S. R. Durham, J. V. Collins, P. K. Jeffrey, D. J. Quint, and A. B. Kay. 1991. Expression of mRNA for interleukin-5 in mucosal bronchial biopsies from asthma. J. Clin. Invest. 87:1541-1546.

14. Kay, A. B., S. Ying, V. Varney, M. Gaga, S. R. Durham, R. Moqbel, A. J. Wardlaw, and Q. Hamid. 1991. Messenger RNA expression of the cytokine gene cluster, interleukin 3 (IL-3), IL-4, IL-5, and granulocyte/macrophage colonystimulating factor, in allergen-induced late-phase cutaneous reactions in atopic subjects. J. Exp. Med. 173:775-778.

15. Carter, B. Z., and J. S. Malter. 1991. Regulation of mRNA stability and its relevance to disease. Lab. Invest. 65:610-621. 